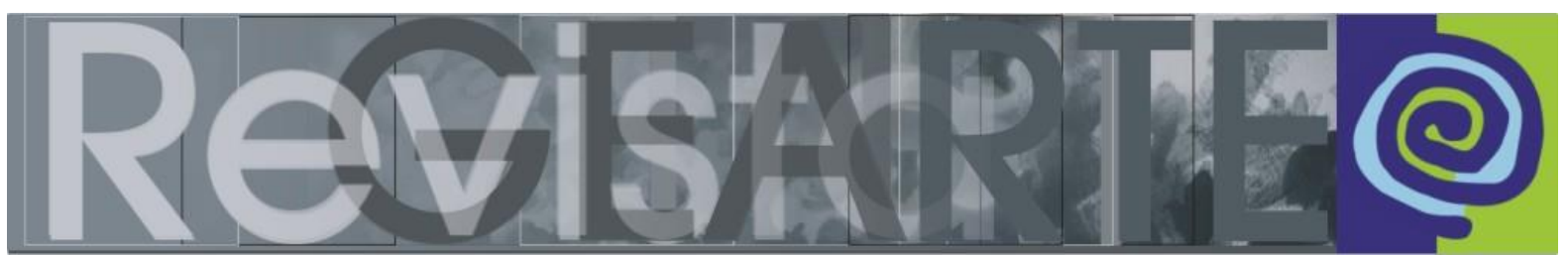

ISSN 2357-9854 | e-ISSN 2596-3198 (online)

\title{
Processos e reminiscências culturais na produção artesanal dos instrumentos do coco de zambê em Sibaúma/RN
}

\author{
Nilton Xavier Bezerra \\ (Instituto Federal de Educação, Ciência e Tecnologia do Rio Grande do Norte - \\ IFRN, Campus Canguaretama/RN, Brasil)
}

\begin{abstract}
RESUMO - Processos e reminiscências culturais na produção artesanal dos instrumentos do coco de zambê em Sibaúma/RN - Na comunidade de Síbaúma, irmãos mestres do coco de zambê do grupo Herdeiros de Zumbi vêm, desde 2006, num processo de recuperação dessa arte existente apenas no Rio Grande do Norte (Brasil). A cultura do zambê envolve a música, a dança e a criação de instrumentos musicais. Das mãos talentosas, surgem tambores, berimbaus e outros instrumentos utilizados nas rodas de coco e de capoeira, bases de um aprendizado musical fundamentado em conhecimentos ancestrais e de ocorrência tradicional na região. $\mathrm{Na}$ artesania necessária à feitura de cada instrumento, a combinação de saberes e matérias-primas locais com produtos vindos do comércio popular possibilitam que o coco de zambê exista, se renove e resista. PALAVRAS-CHAVE
\end{abstract}

Sibaúma. Coco de zambê. Herdeiros de Zumbi. Tambores. Berimbaus.

RESUMEN - Procesos culturales y reminiscencias en la producción artesanal de los instrumentos coco de zambê en Sibaúma/RN - En la comunidad de Síbaúma, los hermanos maestros del coco de zambê del grupo Herdeiros de Zumbi se encuentran, desde 2006, en un proceso de recuperación de este arte existente solo en Rio Grande do Norte (Brasil). La cultura Zambê involucra música, danza y la creación de instrumentos musicales. De las manos talentosas surgen tambores, berimbaus y otros instrumentos utilizados en los círculos del coco y la capoeira, bases de un aprendizaje musical basado en conocimientos ancestrales y de ocurrencia tradicional en la región. En la artesanía necesaria para hacer cada instrumento, la combinación de conocimientos y materias primas locales con productos del comercio popular hace posible que coco de zambê exista, se renueve y resista.

PALABRAS CLAVE

Sibaúma. Coco zambê. Herederos de Zumbi. Tambores. Berimbaus.

\begin{abstract}
Cultural processes and reminiscences in the artisanal production of coco de zambê instruments in Sibaúma/RN - In the community of Síbaúma, brothers who are masters of the coco de zambê from the Herdeiros de Zumbi group, since 2006, they have been in the process of recovering this art that exists only in Rio Grande do Norte (Brazil). The culture of zambê involves music, dance and the creation of musical instruments. From the talented hands, drums, berimbaus and other instruments used in the coconut and capoeira circles emerge, bases of a musical learning based on ancestral knowledge and of traditional occurrence in the region. In the craftsmanship necessary to make each instrument, the combination of local knowledge and raw materials with products from the popular trade allows the coco de zambé to exist, renew and resist
\end{abstract}

KEYWORDS

Sibaúma. Coco de zambê. Heirs of Zumbi. Drums. Berimbaus. 


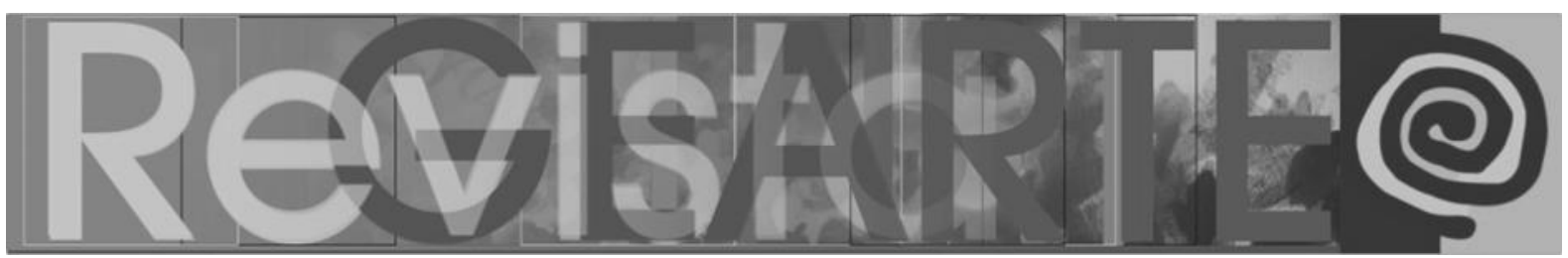

A comunidade quilombola de Sibaúma é um distrito pertencente ao município de Tibau do Sul/RN, situado na microrregião do litoral sul potiguar, nas proximidades da Praia da Barra do Cunhaú, em Canguaretama, e separado desta pela foz do Rio Catu. Em Sibaúma, além de praias belas, coqueirais, manguezais e faixas remanescentes de Mata Atlântica, na praça central do vilarejo, avistamos um monumento composto pelas representações coloridas do berimbau e do tambor, atestando ser ali um lugar onde a capoeira e o coco de zambê se afirmam como tradições ancestrais no cenário norte-rio-grandense. O coco de zambê é uma expressão artística existente somente no Rio Grande do Norte, na qual ritmos musicais são marcados por palmas, cantos coletivos entoados e instrumentos percussivos capazes de entusiasmar os corpos que dançam e se contorcem alegremente.

Zambê significa a dança originalmente praticada apenas por homens (crianças, jovens e adultos), possui um bailado diverso a depender do modo como se desenvolve (individualmente, em pares ou grupos) e aparenta um divertimento, uma saudação religiosa, uma luta, um transe. Em Sibaúma, quando havia interesse das mulheres em participar, abria-se a roda e dançava-se o coco de roda, variação com gestual coreográfico e musical distinto e dançada aos pares. Segundo o antropólogo Raul Lody (2011), acredita-se que os ritmos do coco, além das batidas das mãos, dos pés e do uso de instrumentos membranofônicos, eram marcados pela percussão das metades das cascas do fruto seco e polido do coqueiro. Suas diferentes modalidades são expressões lúdicas das regiões dos engenhos de cana-de-açúcar do Nordeste brasileiro. A etimologia da palavra assemelha-se a "djambê", nome africano para nomear um tipo específico de tambor, diferenciado dos instrumentos locais por possuir uma borda mais larga que a sua base e produzir um som mais agudo.

Outra sutileza que diferencia o coco de roda é a umbigada, interpretada como um convite específico de um dançarino a outro para chamá-lo ao centro da roda. No zambê, a dança é iniciada com o dançarino fazendo uma reverência ao 


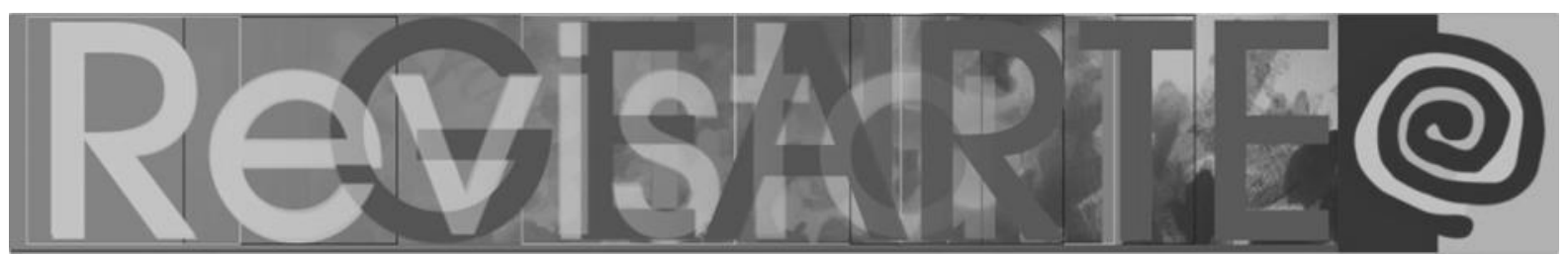

mestre que está conduzindo o toque. Vale ressaltar aqui esse elemento simbólico alusivo aos tambores, no qual os integrantes do grupo prestam homenagem aos instrumentos que determinam o ritmo da música e da dança. Essa caraterística assemelha-se à capoeira, na qual, quando se forma a roda, dois dançarinos se apresentam "ao pé do berimbau" tocado pelo mestre. Este, por sua vez, começa a cantar a ladainha (canto mais curto) ou a chula (canto mais longo) e, em seguida, baixa e levanta o berimbau. Esse gesto indica aos jogadores o início da dança.

O coco de zambê também é conhecido como "pau oco" ou "dança do pau furado" e tem igual representatividade e beleza às da capoeira, porém ainda carece de reconhecimento similar. Essa variação do coco presente sobretudo nas proximidades de regiões canavieiras, de acordo com o pesquisador Cyro Lins (2009), possuía inicialmente a formação instrumental composta por ganzás e dois tambores, um grande, de aproximadamente um metro e meio a dois metros (zambê) e de som mais grave, e outro menor, não ultrapassando um metro (chama) e de som mais agudo. Os tambores feitos em Sibaúma apresentam dimensões aproximadas.

Figura 1 - Grupo Herdeiros de Zumbi, Sibaúma, 2018

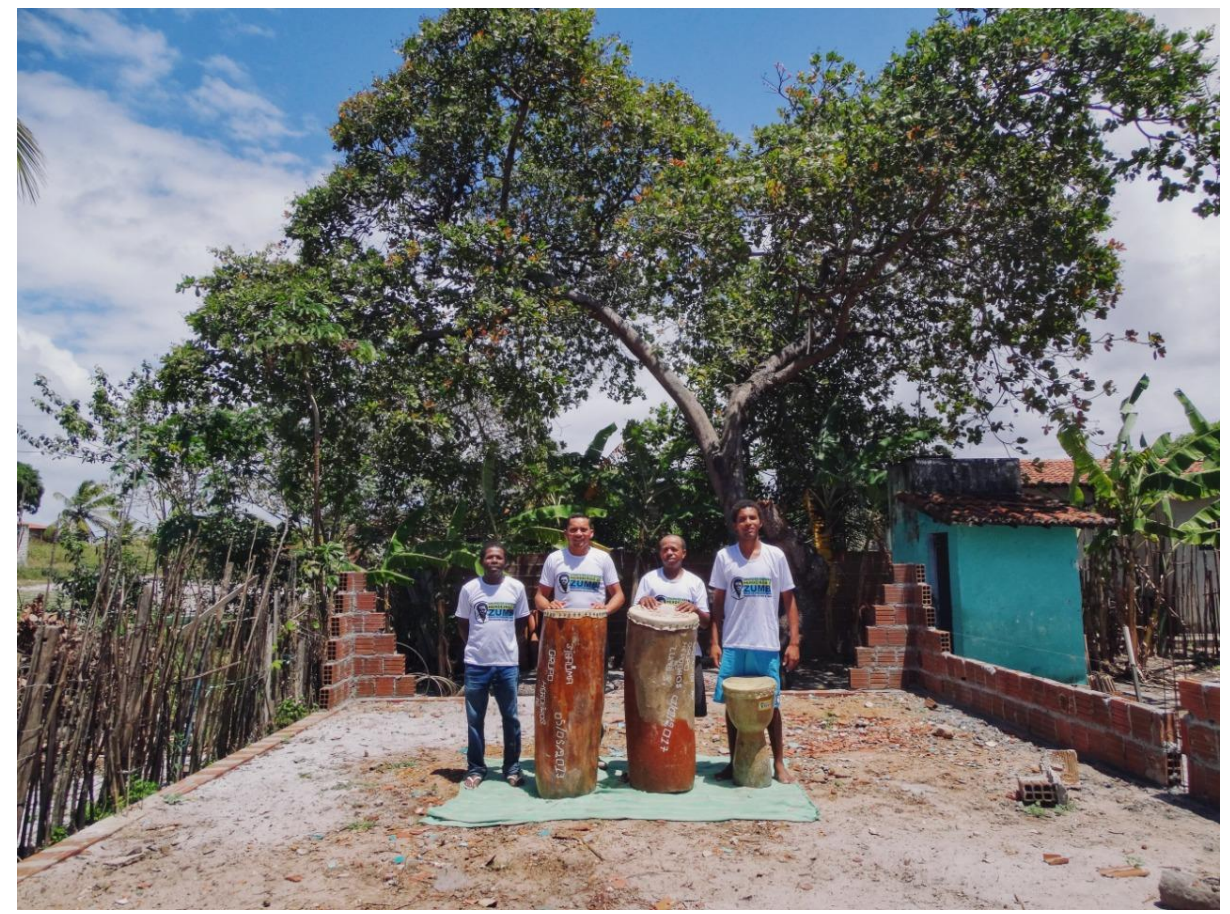

Fonte: Isaac Melo (2018).

BEZERRA, Nilton Xavier. Processos e reminiscências culturais na produção artesanal dos instrumentos do coco de zambê em Sibaúma/RN.

Revista GEARTE, Porto Alegre, v. 7, n. 3, p. 601-619, set./dez. 2020.

Disponível em: http://seer.ufrgs.br/gearte 


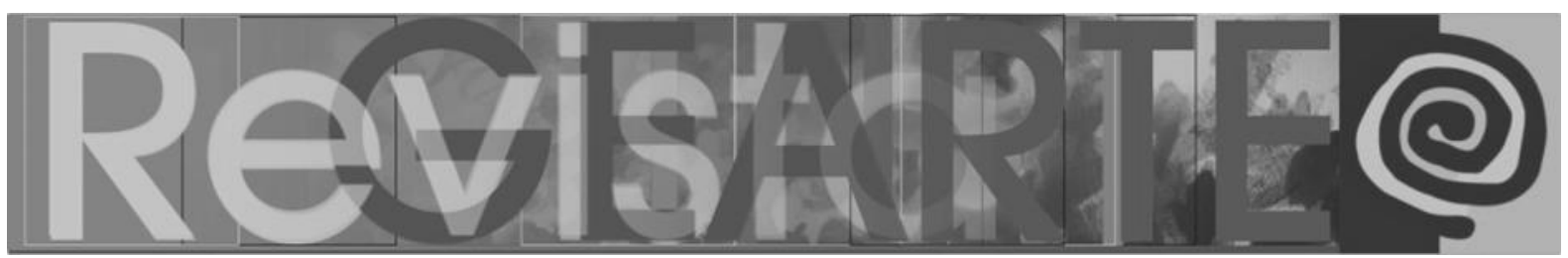

Atualmente, essa composição passou por alterações com a inclusão de outros instrumentos utilizados na música do coco, como veremos adiante. Para a produção musical do zambê, são confeccionados tambores esculpidos em madeira e revestidos com couro natural. No contexto de Sibaúma, dominam esse ofício os irmãos Sérgio e Laelson Marques Caetano, integrantes do grupo Herdeiros de Zumbi, formado também pelos músicos Josinaldo Rosa da Silva e Evandeilson Leandro. Em sua performance, o grupo, que se apresenta regularmente, também incorpora o berimbau e o ganzá, singularizando sua produção musical. É importante ressaltar que os Caetano, juntamente com Leandro e Camilo, constituem uma base familiar comum que originou Sibaúma (CAVIGNAC; LINS; MAUX, 2006).

Além disso, o Herdeiros de Zumbi é responsável por organizar, há aproximadamente onze anos, dois importantes eventos na comunidade, a Noite dos Tambores no mês de fevereiro e o Dia da Consciência Negra em novembro. Esses eventos são planejados visando à participação primordial dos moradores de Sibaúma e em suas programações constam artistas e grupos escolares convidados para atividade nas microrregiões agreste, litoral sul potiguar e, também, na capital. Vale salientar que, nos últimos anos, observamos notória e progressiva participação de turistas de passagem por Sibaúma e, também, vindos das praias da Pipa e Barra do Cunhaú (cobiçados destinos turísticos do Rio Grande do Norte situados na vizinhança). Somam-se a esse grupo professores, estudantes, artistas e pesquisadores oriundos de diversos lugares e interessados em cultura popular para conhecer o coco de zambê. Os dois momentos são entendidos como espaços para afirmação da cultura negra.

$\mathrm{Na}$ tese de Teodora Alves (2003), Herdanças de corpos brincantes: os saberes da corporeidade/africanidade em danças afro-brasileiras, a autora cita o trecho de um diálogo com o Mestre Geraldo Cosme, responsável pelo grupo de zambê mais divulgado do Rio Grande do Norte e residente em Cabeceira, outro 


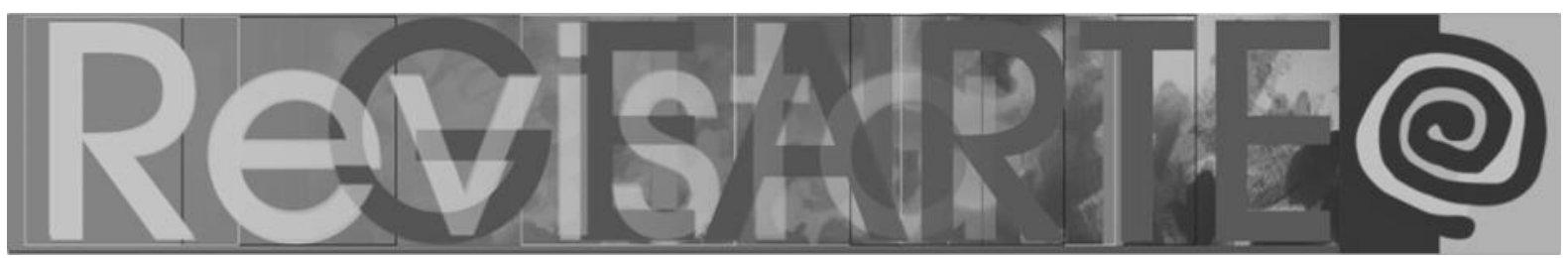

distrito de Tibau do Sul. Esse registro atesta que a existência do coco de zambê em Sibaúma não é recente:

Mestre Geraldo veio até a varanda e aproveitei para perguntar-lhe sobre as pessoas mais antigas que brincavam o Zambê, pois gostaria de conversar com algumas. Ele citou alguns nomes de pessoas que moram em Cabeceiras, na praia de Pipa e na praia de Sibaúma. Falou de outras que já haviam falecido, mas que tinham os filhos ainda vivos. (ALVES, 2003, p. 118-119)

O espaço de origem e de maior ocorrência do coco de zambê no Rio Grande do Norte é atribuído à região de Tibau do Sul, na qual está situada Sibaúma. A partir de 2006, os irmãos Sérgio e Laelson assumiram a responsabilidade de recuperar efetivamente a prática do coco de zambê na comunidade com o apoio de amigos e familiares, depois de um período de alternâncias no interesse dos brincantes locais. Por considerarmos 0 artesanato como uma prática cultural indissociável de outras dimensões da vida, vem desse referido contexto a recuperação simultânea dos saberes necessários para a feitura dos instrumentos tão essenciais à música e à dança características da comunidade.

Nesse sentido, os tambores e berimbaus de Sibaúma aproximam-se da categoria de "artesanato tradicional, cultural ou de raiz", conceitos nos quais os objetos materializam fortes marcas da cultura em que são gerados. Por essa razão, não estão restritos à condição de simples mercadorias, pois são capazes de traduzir a identidade de quem os produziu, seja um indivíduo ou uma coletividade (LIMA, 2010). Outro aspecto que os aproxima dessa classe é o tempo diferenciado, condição subentendida à produção atenciosa desses objetos, discordante da celeridade do ritmo industrial e massivo que também desconsidera as irregularidades formais que os particularizam. 


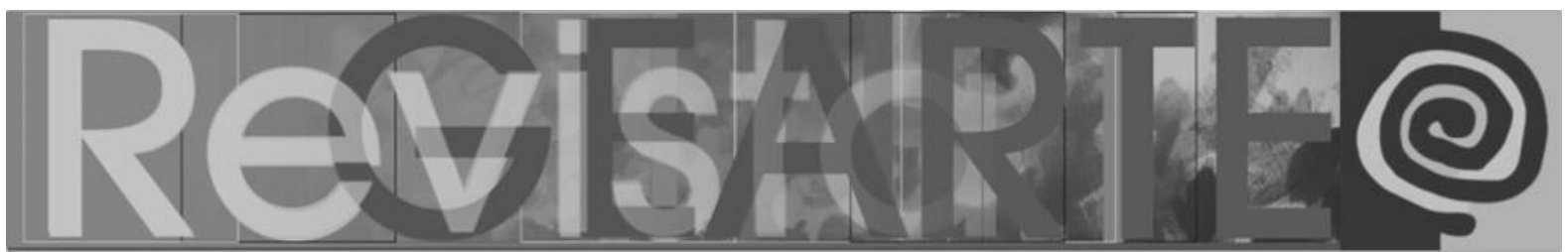

Figura 2 - Tambores do coco de zambê de Sibaúma

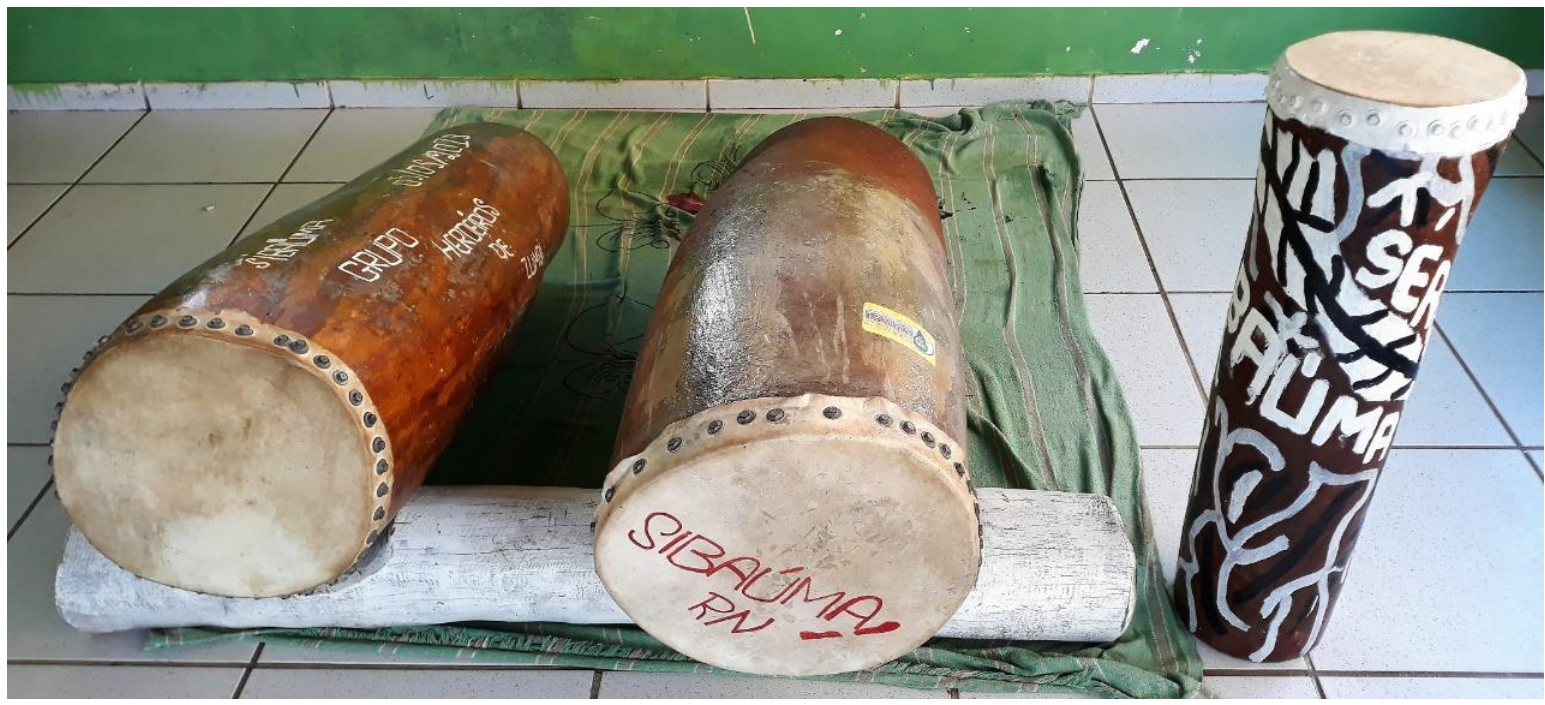

Fonte: foto do autor (2018).

\section{A feitura do pau furado}

Figura 3 - Sérgio Marques Caetano, mestre construtor dos tambores do coco de zambê, Siabúma

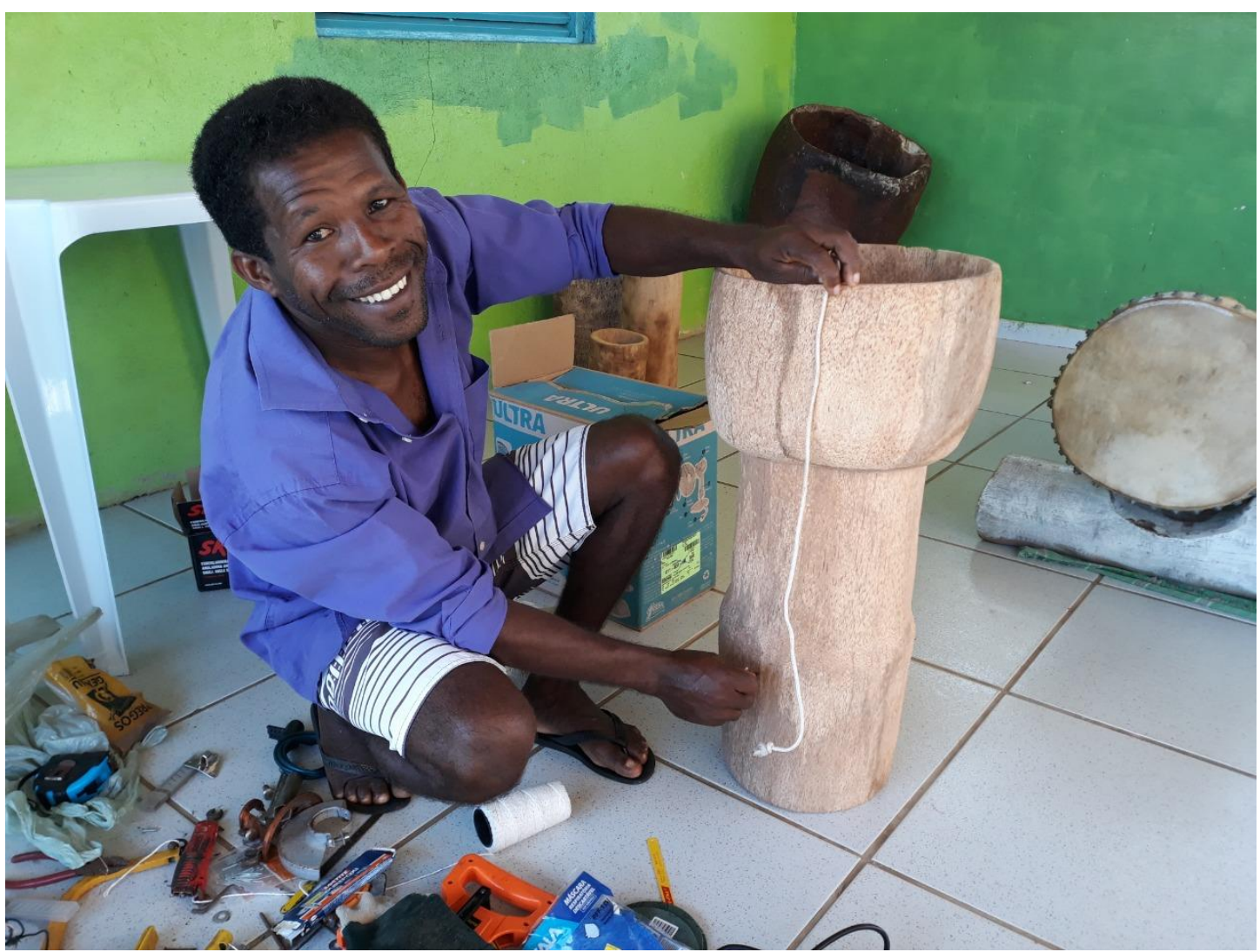

Fonte: foto do autor (2018).

BEZERRA, Nilton Xavier. Processos e reminiscências culturais na produção 606 artesanal dos instrumentos do coco de zambê em Sibaúma/RN.

Revista GEARTE, Porto Alegre, v. 7, n. 3, p. 601-619, set./dez. 2020

Disponível em: http://seer.ufrgs.br/gearte 


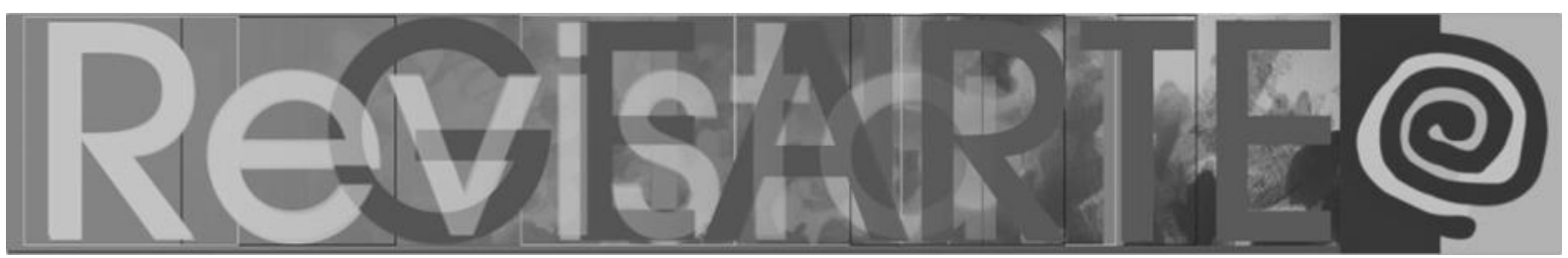

Previamente, esclareço nossa compreensão sobre artesanato como um fazer no qual predomina o exercício da manualidade e o uso de ferramentas, maquinários ou instrumentos auxiliares são secundarizados pelo protagonismo do gesto humano. Da mesma forma, não compreendemos olhares hierarquizantes que instituem afastamentos entre as categorias "arte" e "artesanato" por considerar que tanto o trabalho manual quanto o intelectual são dimensões acionadas durante os processos de produção dos objetos.

Os tambores e berimbaus, responsáveis pelo ritmo da música e da dança do coco de zambê em Sibaúma, nascem das mãos habilidosas dos irmãos Sérgio e Laelson Marques Caetano, exímios conhecedores do processo de elaboração desses instrumentos. O processo de artesania dos tambores requer o uso de madeiras nativas específicas selecionadas "pelos antigos", conforme assinala Sérgio, são elas: cajueiro (Anacardium occidentale); imbiridiba (Eschweilera ovata), também conhecida como imbiriba e biriba, e popularmente dividida em três espécies, imbiriba d'água, imbiriba de jacu e imbiriba branca; jitaí ou jatobá da mata (Hymenaea courbaril) (LORENZI, 1998), além do coqueiro (Cocos nucifera) originário da Índia (LODY, 2011).

Não se ousa derrubar as árvores, basta identificar aquelas que tombaram naturalmente carcomidas pela ação silenciosa dos cupins no meio da mata ou dos quintais. Numa ida aos fragmentos remanescentes de mata da região para visualizarmos as árvores selecionadas para a elaboração dos tambores, nas companhias de Sérgio e Laelson, ouvimos relatos de memórias sobre o uso do território, num tempo em que havia livre circulação pelos moradores de Sibaúma. Hoje em dia, essas mesmas áreas foram interditadas e transformadas em propriedades privadas, exigindo mediações para o acesso e dificultando muito o uso das madeiras nativas pelos moradores. Outros impeditivos foram os sucessivos desmatamentos para a construção de grandes empreendimentos imobiliários, formação de pastos e canaviais na região. Nesse mesmo contexto, observamos na voz de Sérgio a manutenção de um hábito ancestral e belo de pedir 


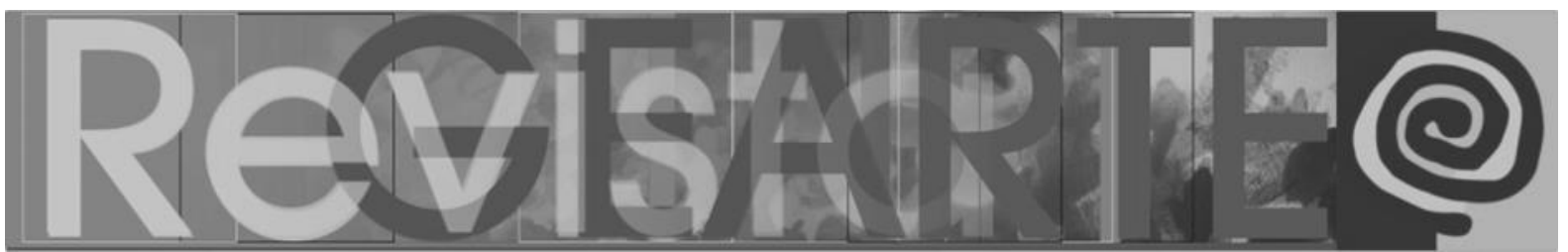

permissão aos encantados presentes na natureza para entrar na mata: "Senhora da Mata, Mãe da Mata, dá licença pra gente tirar um pau".
Figuras 4 e 5 - Os irmãos Sérgio e Laelson identificam árvores nativas de imbiriba em fragmento de mata ciliar às margens do Rio Catu

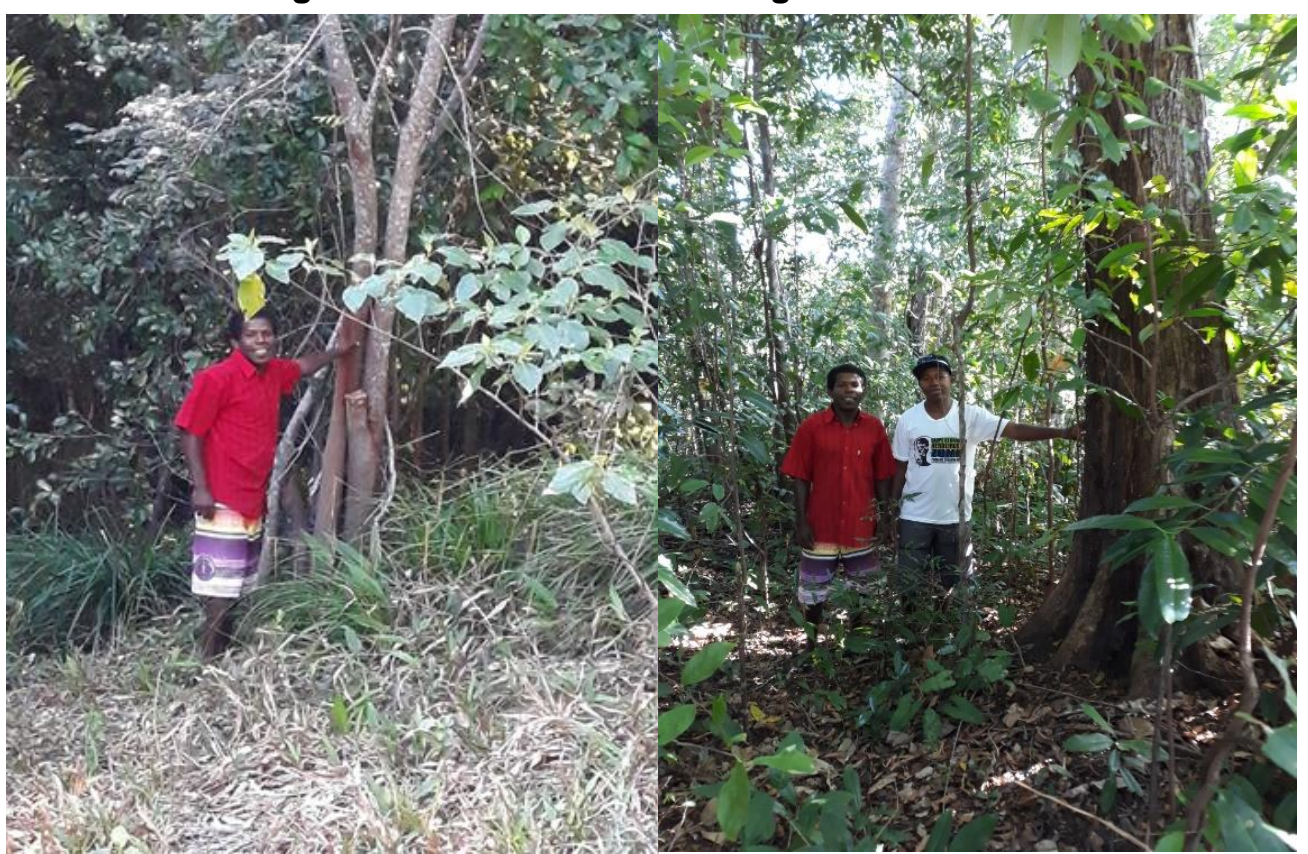

Fonte: fotos do autor (2018).

Sérgio se especializou na confecção de tambores. Suas ferramentas de trabalho e demais produtos utilizados consistem, além da madeira, em alicate, chave de boca, fio de cobre, luva de borracha e tecido, formão, enxó, arco de serra, cola branca, "pedaço de pau" utilizado como martelo, tesoura de ponta, lixadeira, máscara (para evitar a inalação do pó da madeira), lâminas de ferro adaptadas, estilete, folhas de lixas para polimento (numeração 60, 80 e 100), tinta a óleo para decoração, pregos, parafusos, cordão de seda, furadeira, querosene, couro natural de vaca (mais resistente) e, eventualmente, couro de carneiro (mais macio e menos durável).

A nomenclatura popular dos berimbaus da capoeira, divididos geralmente em gunga, médio e viola, determina o tipo de som produzido por cada instrumento: o primeiro é mais "rouco", grave; o segundo é mais agudo; e o último "se desdobra". A princípio, os tambores do zambê não recebiam nomes específicos, porém, 


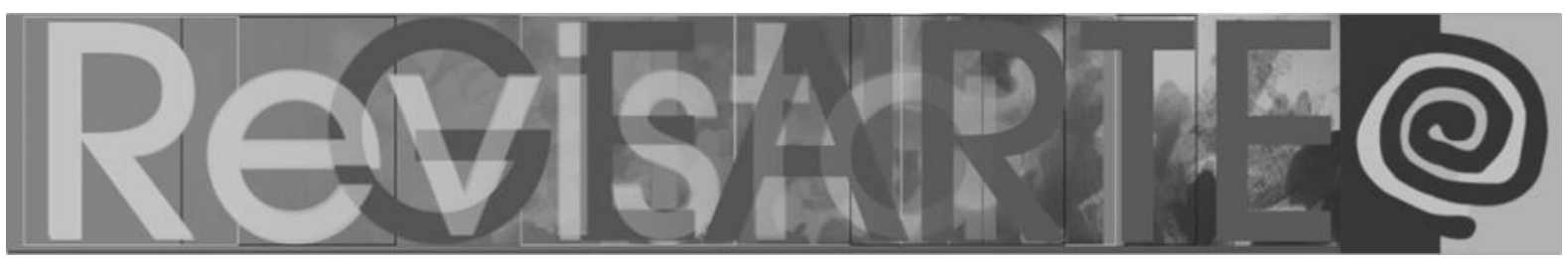

Sérgio se apropriou dos termos utilizados para nomear os berimbaus da capoeira e, particularmente, identificou os instrumentos do zambê, dispostos no "centro dos tambores" (base de apoio feita de tronco de coqueiro na qual são dispostos). Nesse caso, sua terminologia compreende o gunga ou mestre, colocado ao centro e responsável pelos sons agudos; o médio, portador de sons graves; e a chama, responsável por "disparar o toque, semelhante a um cavalo manco".

Para a confecção dos tambores verificamos quatorze fases de elaboração, considerando a totalidade do processo. O primeiro passo consiste no recolhimento da madeira procedente das extensões de mata que subsistem na região ou do entorno das casas da comunidade; a depender da espécie, sem o sacrifício da árvore, conforme dito antes, esse costume é herança ancestral. Preferencialmente são selecionadas madeiras "veladas", ou seja, já em processo de secagem natural e caídas em dias anteriores, contudo, isso não significa que o recolhimento de madeiras "verdes" também não aconteça. Hoje em dia, o uso de madeiras nativas ou com "miolo" está cada vez mais raro pela falta de acesso direto dos moradores às faixas de mata, situadas notadamente em propriedades privadas. $O$ transporte para o espaço de trabalho é feito com o auxílio de motocicleta ou carro de mão.

Sérgio utiliza espaços livres na lateral ou no quintal da residência de sua família para trabalhar, iniciando os tambores nesse local e concluindo o processo no quintal da casa de seu irmão Laelson, um pouco mais afastada do centro de Sibaúma. Na sequência, a madeira é descascada e lavrada com o auxílio de um enxó (instrumento cortante de cabo curto) e depois é escavada manualmente com lâminas de ferro e formão. Madeiras afetadas por cupins são desejáveis porque ao perfurar a árvore o inseto adianta o trabalho de escavação, facilitando essa parte do processo. A quarta fase compreende o polimento das superfícies com folhas de lixas apropriadas para eliminar imperfeições mais aparentes e obter uma textura mais lisa e uniforme. 


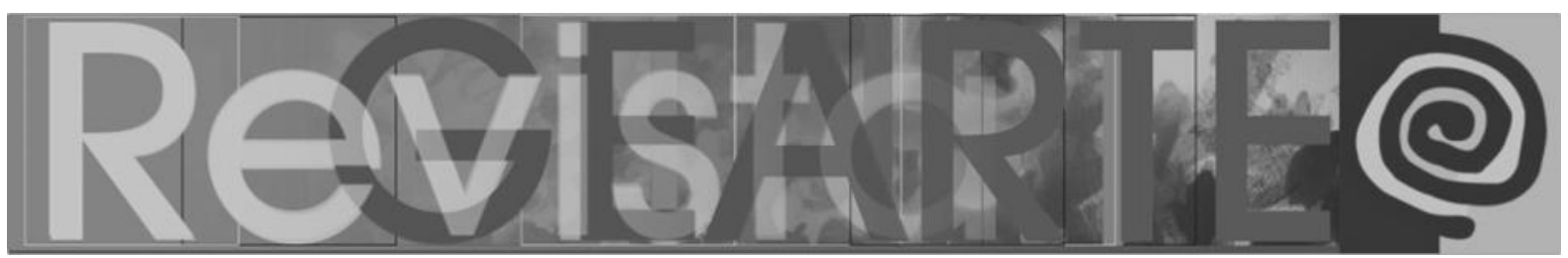

A aplicação de querosene é o próximo passo, o produto é aplicado com o pincel ou reutilizando uma embalagem de desodorante spray de modo a embeber completamente a madeira. Seu uso é justificado por duas razões: como preventivo ao ataque de insetos que danifiquem a madeira e, também, para endurecê-la ou, como diz Sérgio, "ficar fixe". É necessário após a aplicação do querosene que haja um intervalo de tempo pelo menos de um dia para o outro. Na sequência, o pó fino da própria madeira acrescido de cola branca compõe uma massa a ser espalhada em toda a superfície do instrumento, dando um acabamento menos áspero.

Posteriormente, o emprego de lixa fina significa um cuidado derradeiro para a remoção de eventuais grânulos de massa, tornando a madeira cada vez mais limpa e macia ao toque. A oitava parte do processo envolve a aplicação de cola branca pura, sem adição de água, para dar brilho e melhorar a qualidade do acabamento. Ao final, é necessário mais um tempo de descanso, de um a dois dias para garantir a secagem completa do produto. Até aqui temos a preparação atenciosa da madeira que servirá como base ou corpo do instrumento, em seguida, as etapas abrangerão o encouraçamento do tambor.

Para receber o couro que será esticado na borda ou "boca" do instrumento, a madeira é perfurada e os parafusos são encravados próximos à base do tambor no lado oposto àquele onde o couro será estendido e fixado. Não há medidas ou distâncias exatas, a matemática é desobrigada dos rigores e submetida livremente ao julgamento visual construído pela experiência adquirida pelos mestres. Esses parafusos não são elementos definitivos e servirão apenas para sustentar a tensão provocada pelo estiramento do couro preso aos fios de seda. As arestas de madeira à sua volta são desprezadas com a ponta de um estilete.

O couro utilizado na produção dos tambores do zambê é procedente de lojas de artigos religiosos na capital ou do município de Goianinha, revendido e beneficiado em círculos, adaptados ao formato dos atabaques presentes nos cultos das religiões de matriz africana, às vezes, são adquiridas peças maiores 


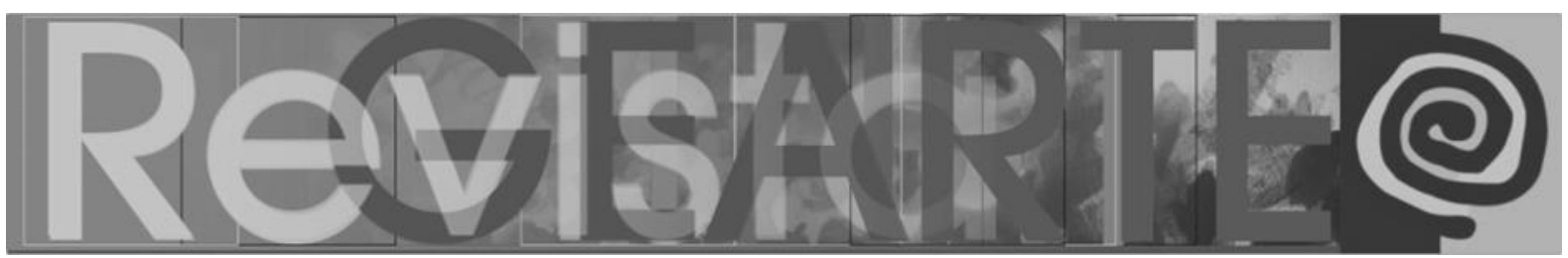

quando se consegue o couro de animais abatidos na região. Além da durabilidade, há outra diferença na opção pelos couros de vaca ou de carneiro, o primeiro proporciona sons mais graves e o segundo sons mais agudos. Para ser usado, o couro precisa amolecer na água por cerca de vinte minutos ou além disso. Peças maiores ou não trabalhadas demoram mais para amolecer, podendo levar até dois dias. O uso do couro cru determina que o processo de feitura do instrumento seja exposto por 40 noites ao sereno e 40 dias ao sol para que se amolde perfeitamente à base de madeira.

Para o encouraçamento do tambor ou esticamento do couro, são feitas na peça constantemente molhada perfurações com a ponta de uma tesoura afiada em suas bordas deixando propositalmente uma margem. Para furar a borda do couro não se usa só a tesoura mas também estilete. Os intervalos dos furos no tambor são quase de um centímetro de um furo para o outro, não é um ato simples porque o material oferece resistência. Não há aqui preocupação alguma em utilizar instrumentos de medida, "é tudo no olho!", nos diz Sérgio.

Pelas aberturas da madeira são transpassados fios de seda amarrados em nós chamados de "enforca gato", técnica aprendida com outro morador de Sibaúma. Os fios são presos aos parafusos inicialmente achegados à base do instrumento e esticados com força, tendo o amparo de uma chave de boca. Nessa fase do trabalho, Sérgio apoia suas mãos no couro preso na borda do tambor e solicita o apoio de Laelson para esticar os fios de seda e, por conseguinte, a peça de couro que se amolda progressivamente ao formato da boca do instrumento. É importante ressaltar aqui a atenção dos irmãos músicos em testar simultaneamente e repetidas vezes a qualidade do som do novo tambor, pela primeira vez audível nesse estágio do processo. Ouvidos experientes e apurados se animam e preveem a boa qualidade do tambor. A prática é concluída com o tambor exposto à ação do sol e do sereno por um a dois dias até se ajustar completamente ao formato da borda de madeira. 


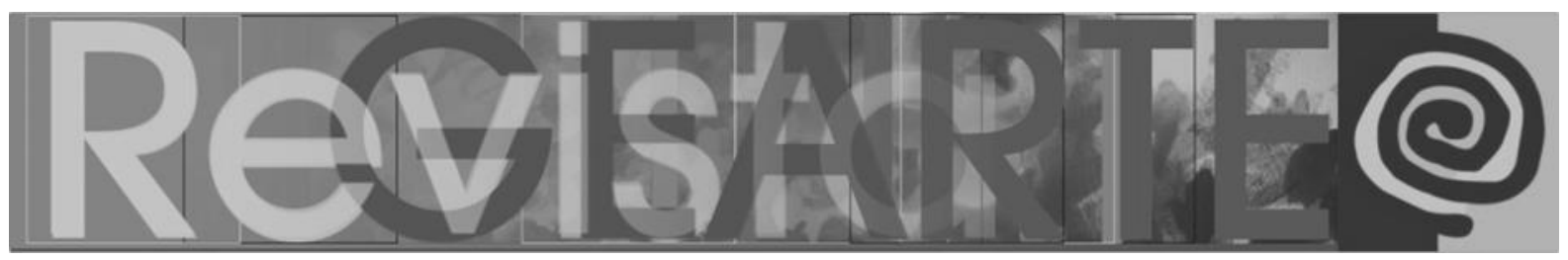

Figuras 6 e 7 - Parte do processo de encouraçamento de um tambor

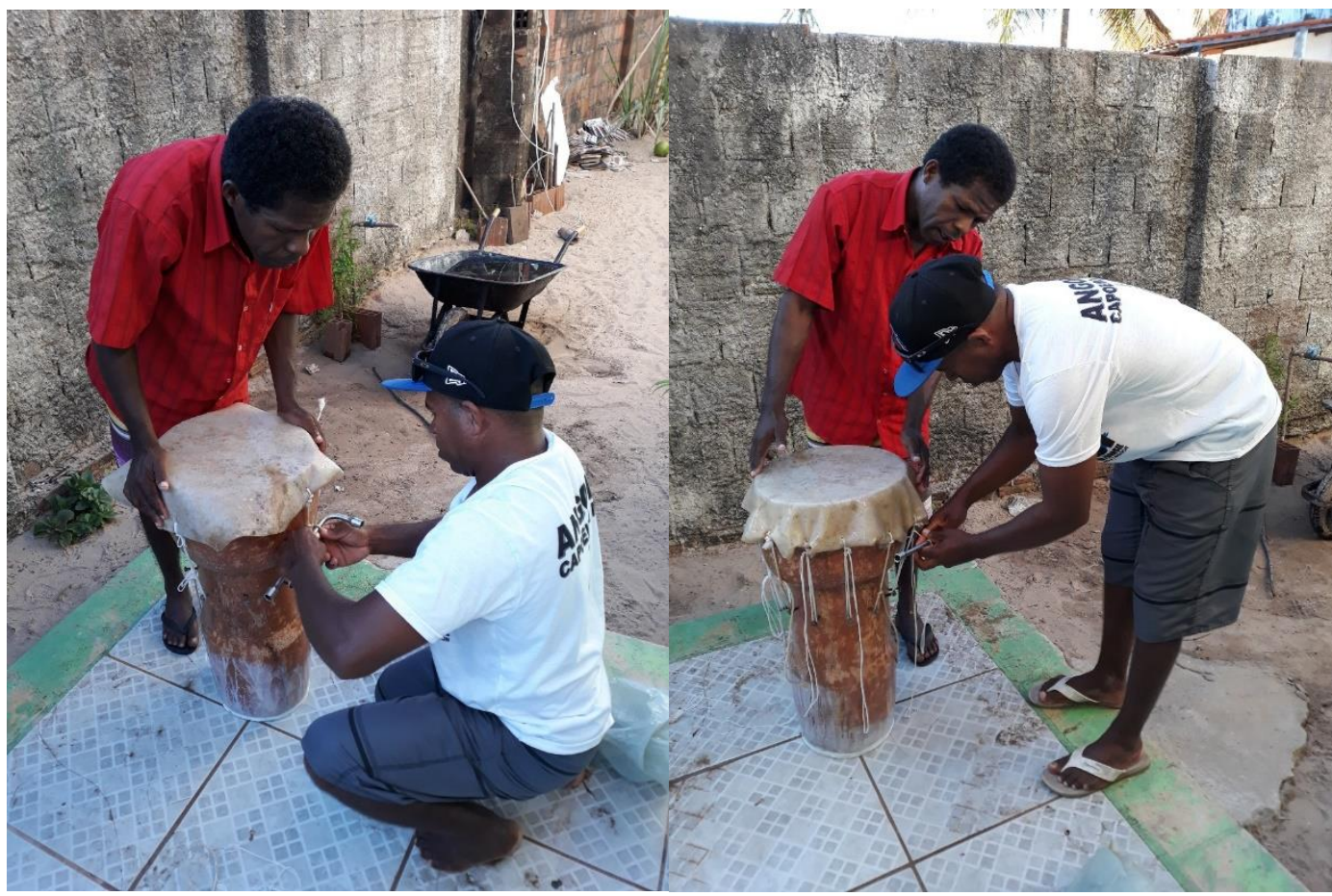

Fonte: foto do autor (2018).

O arremate do tambor é feito com o acréscimo dos parafusos dispostos nas margens de sua beirada. Utiliza-se hoje em dia parafusos, porém, nos primeiros tambores Sérgio utilizava pregos. Na sequência, é feita a retirada dos parafusos da base, as aberturas são preenchidas com massa de pó de madeira e cola, e realiza-se o corte do couro excedente. Fisicamente o tambor está pronto, entretanto, a arte de Sérgio expande sua dimensão estética acrescendo pinturas de sua autoria feitas com tinta a óleo com poucas cores: preto, branco, vermelho ou azul, sua cor preferida. Os motivos se diversificam: a assinatura do artista é ampliada, ressaltando seu aspecto gráfico entre motivos abstratos; alguns tambores recebem o nome de Sibaúma, a data de fabricação ou o adesivo com a logomarca do grupo Herdeiros de Zumbi do qual Sérgio é um dos organizadores e participante. No coletivo, ele vivencia e conduz ensaios e apresentações do coco de zambê e da capoeira. A depender do tamanho do tambor, o processo completo pode variar entre quinze a trinta dias. 


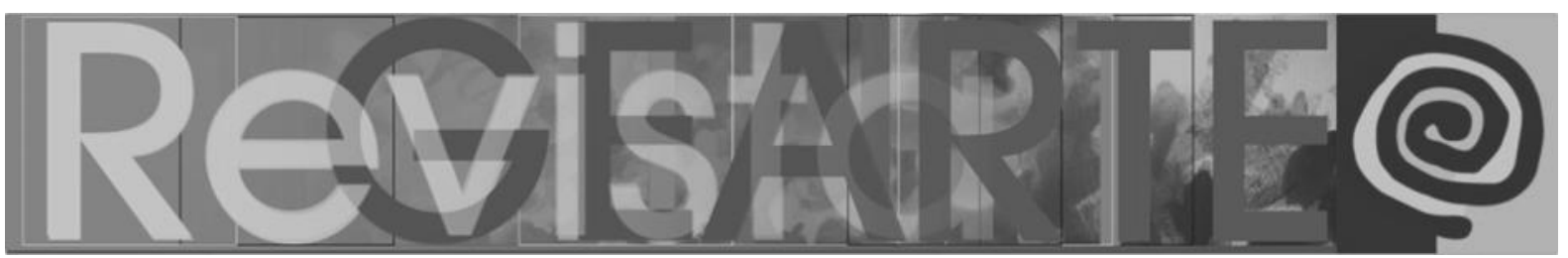

Figura 8 - 0 "esquente" dos tambores diante da fogueira, feito momentos antes da apresentação do grupo Herdeiros de Zumbi durante a realização de um dos eventos na comunidade de Sibaúma, 2018

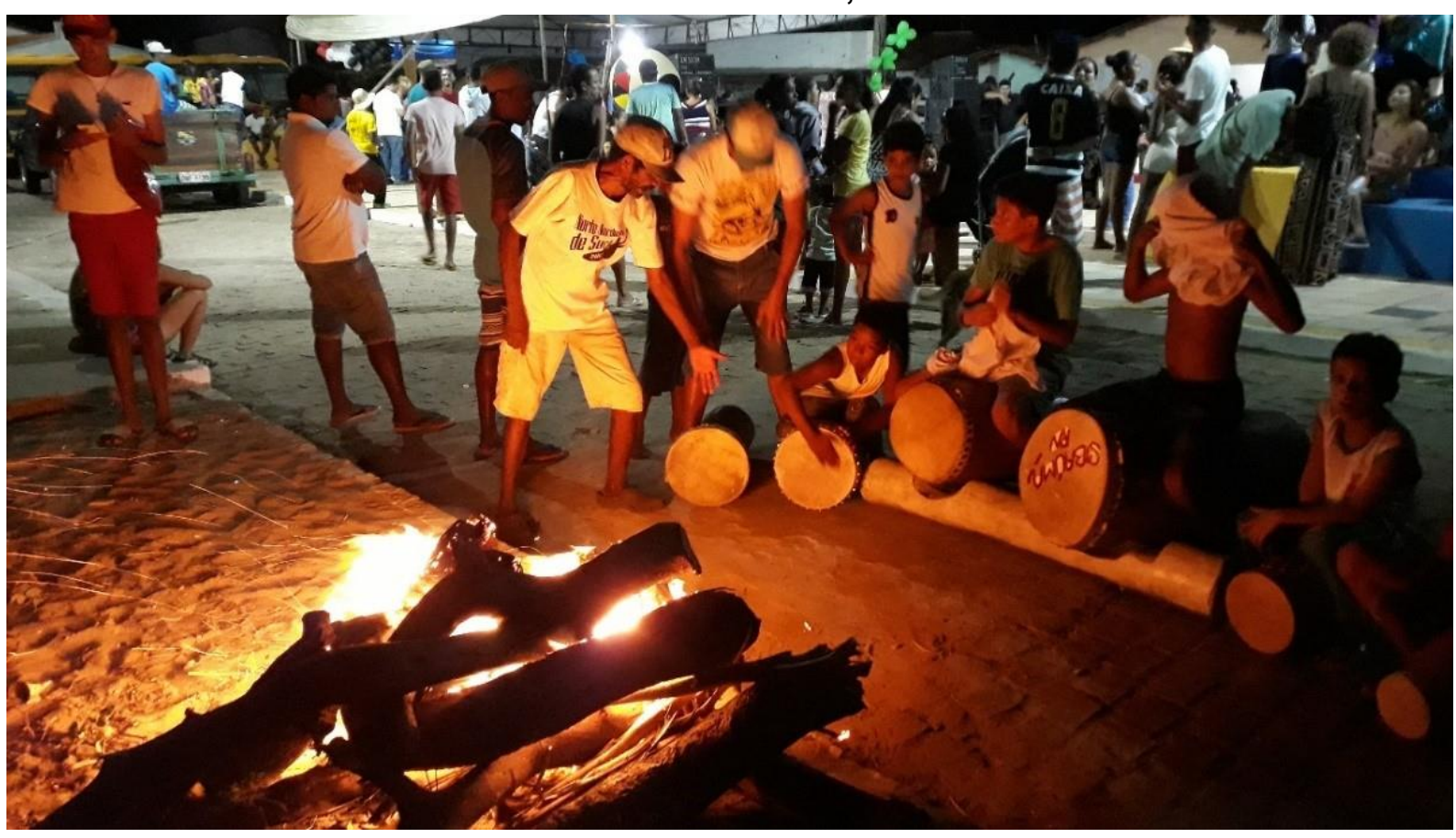

Fonte: foto do autor (2018).

O "esquente" do couro igualmente está inserido na preparação do tambor com duas finalidades bem definidas: para se obter uma melhor sonoridade $\mathrm{e}$ assegurar a durabilidade do couro. A cada apresentação do coco de zambê, os tambores são colocados próximos às chamas de uma fogueira para contrair o couro. "Se o couro esfriar muda o som, o couro de um instrumento numa roda de zambê não pode estar frio porque senão não tem som, fica um som moco", conclui Sérgio.

\section{Os saberes para a preparação dos berimbaus}

A confecção dos berimbaus em Sibaúma também exige sucessivos estágios, começa com a retirada de um galho ou "verga" na mata, são preferidas aquelas extraídas de árvores de madeira fibrosa, porém flexível, como imbiriba, ubaia, sapucaia, mamãozinho ou pereiro. O tamanho costuma obedecer às medidas de $1,5 \mathrm{~m}$ de comprimento e $25 \mathrm{~mm}$ de espessura. $O$ próximo passo consiste na retirada da casca ou da fibra que envolve o miolo, e então a madeira 


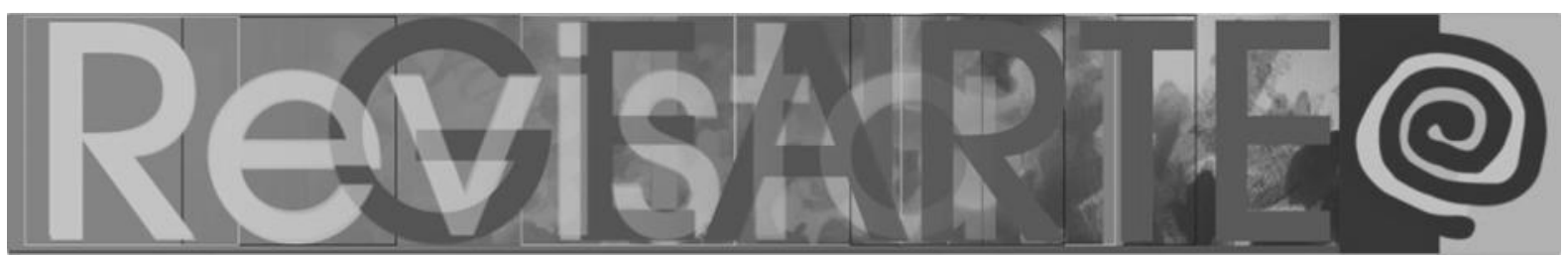

passa por um período de repouso de três semanas. Segue o processo de raspagem feita com caco de vidro ou estilete para a retirada de nós, o acabamento continua com o polimento feito com lixa fina.

De acordo com Laelson, para determinar o corte do tamanho do berimbau, medem-se sete palmos após o corte e é feito o "pé" do berimbau. Para isso, um arco serra é empregado para fazer a marcação, e o desbaste da madeira é feito com estilete. O arame obtido de pneus de caminhão, considerado mais "fixe" (resistente) e de melhor sonoridade, é fixado na "cabeça" do berimbau (extremidade oposta ao pé) onde é aderida com prego uma rodela de couro (ou sola de cinturão de cela). Após a fixação do arame, ele é cortado, deixando uma sobra ou ponta para fazer um trançado. Somente nesse ponto do processo é feita a envergadura característica do arco do berimbau, e abaixo do arame é preso um cordão (barbante de algodão) para evitar que o arame desça.

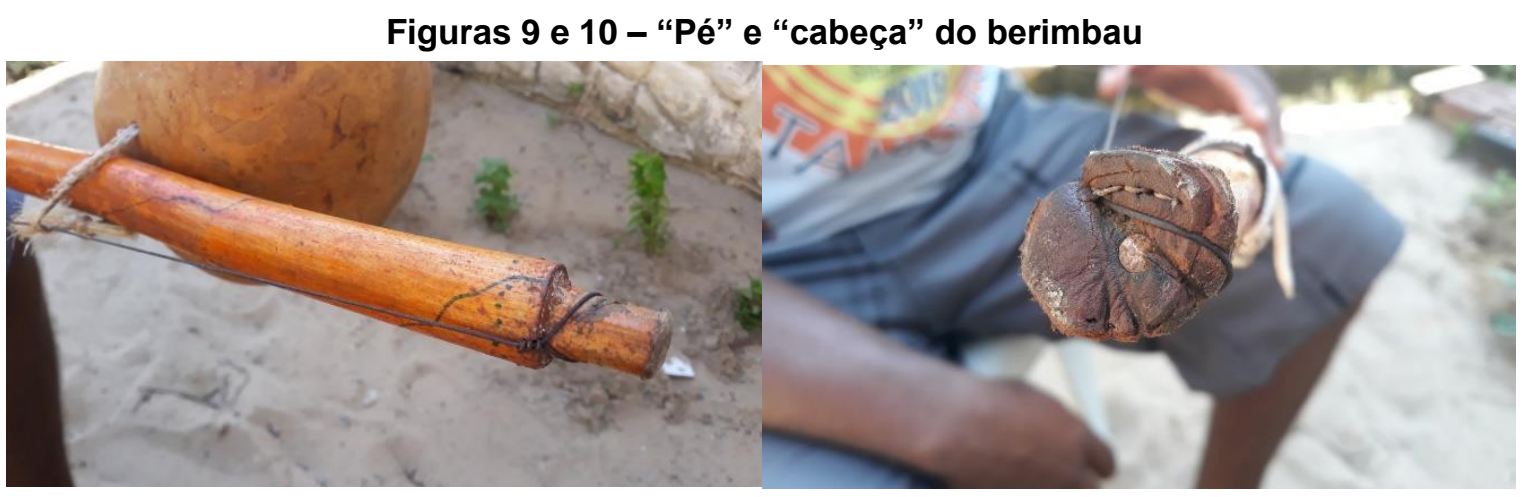

Fonte: fotos do autor (2019).

A planta que fornece a cabaça ou cuia (Lagenaria siceraria) é uma trepadeira intencionalmente cultivada para obtenção de seu fruto, que também é conhecido como "cabeça" do berimbau e colhido em terrenos baldios, doado por amigos ou comprado quando apresenta o tamanho aproximado de um palmo. Comumente é colhida verde, amadurecendo ou seca. Sua secagem é necessária e é preciso secar ao sol por até quinze dias, algumas apodrecem durante o período de secagem, inviabilizando o processo. A depender do tipo, o berimbau pode apresentar variações, pois o que diferencia entre gunga, médio e viola é o tamanho 


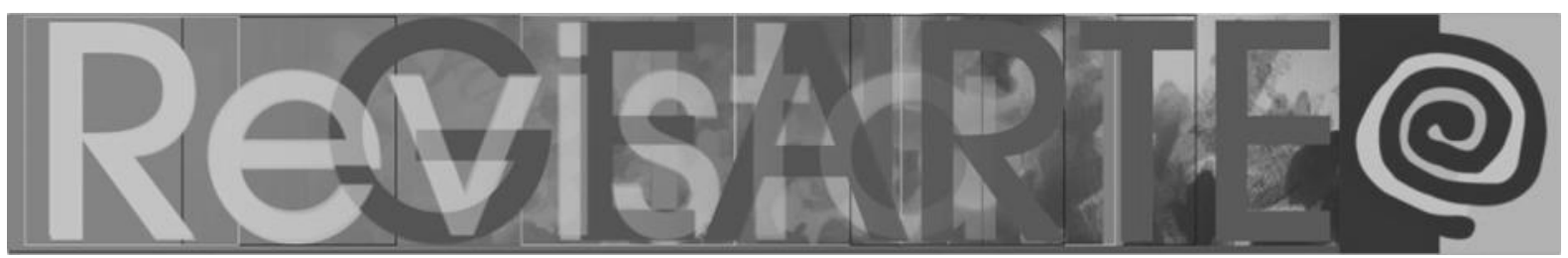

da cabaça, de acordo com os irmãos Caetano. "O gunga tem que ter uma cabeça grande pra que possa dá um som berrante, a cabeça do médio já torna menor e agudo e o viola tem que ter a cabeça pequena para dá um som afinado".

Figuras 11 e 12 - Detalhe apresentando a fixação da cabaça no berimbau e o caxixi

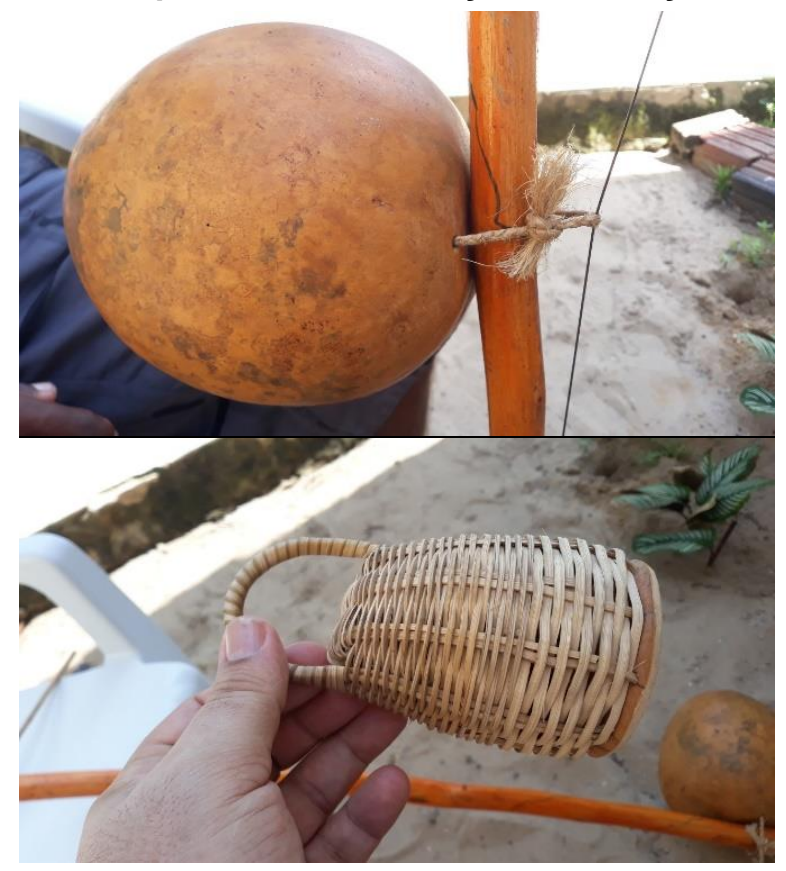

Fonte: fotos do autor (2019).

Para fixar a cabaça, também não há exatidão, pois depende da envergadura e do som que se deseja. Normalmente, ela é fixada cerca de um palmo a partir do corte do pé do berimbau. Para tanto, são feitos dois furos para passar o cordão e segurar a cabaça na verga. Na cabaça fechada é feito um corte no alto com a ponta de uma tesoura ou com uma chave de fenda, a seguir é feita a limpeza do seu interior e, no fundo, a marcação do local (aproximadamente com largura de dois dedos). Colocado o cordão, é dado um nó para a fixação na verga e no arame, e é importante que o nó fique justo. A fase final compreende o envernizamento ou decoração do berimbau.

Outros instrumentos são utilizados na capoeira, dentre os quais o caxixi, tocado junto com o berimbau com a função de disfarçar alguma falha em seu toque e, também, ajudar no ritmo (BRITO, 2008). A confecção do caxixi começa pela 


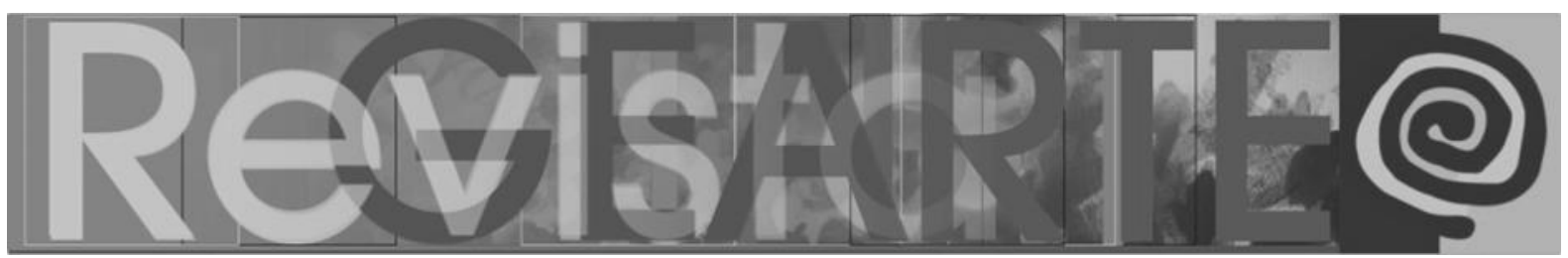

base feita num pedaço de cabaça (novamente não há exatidão nas medidas). Nessa base, são feitos onze furos, o número de furos necessita ser ímpar e nunca pode ser par. Em cada furo é passada fibra do junco, palha de coqueiro, fita plástica ou fitilho (materiais empregados pelos artesãos em Sibaúma) para formar duas "pernas" que orientarão o trançado que dará a forma do caxixi, fechado em um nó com a sobra da fibra. Para finalizar esse instrumento são depositados em seu interior sementes de plantas como "olho de pombo" ou "olho de cobra" (Abrus precatorius).

Complementam a música da capoeira a baqueta empregada para tocar o berimbau, medindo pouco mais de dois palmos e que em Sibaúma é proveniente de uma "galha" fina de árvores nativas como a "angélica" ou de plantas arbustivas como a Guabiraba (Campomanesia xanthocarpa). Complementando a baqueta, para produzir o som característico do berimbau e, também, para obter a mudança das notas musicais, utiliza-se uma pedra (seixo rolado) do tamanho aproximado de uma moeda.

\section{Miniaturas para mostrar a cultura}

Figuras 13 e 14 - Miniaturas dos instrumentos produzidos em Sibaúma; aula sobre coco de zambê para estudantes de uma escola do município de Nísia Floresta/RN, no Dia da Consciência Negra

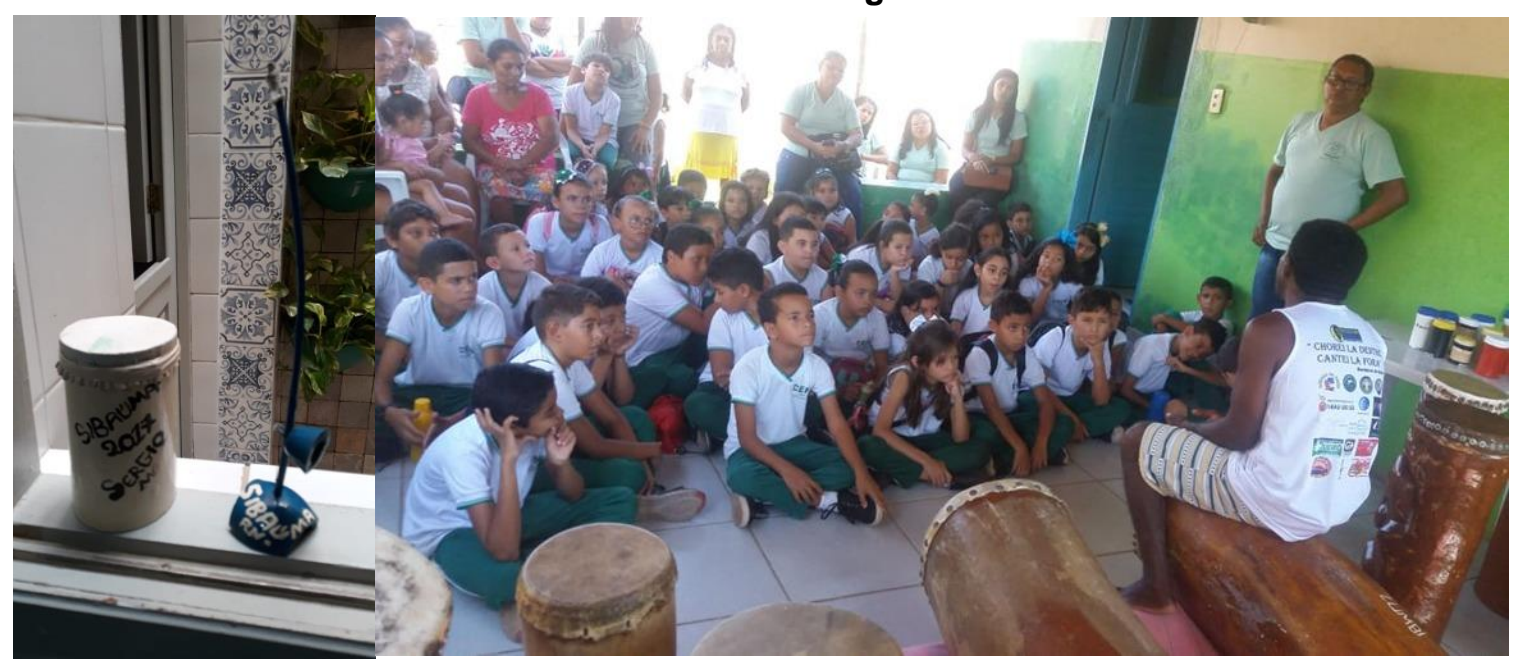

Fontes: foto do autor (2020) e Jaelson Marques Caetano (2019).

BEZERRA, Nilton Xavier. Processos e reminiscências culturais na produção 


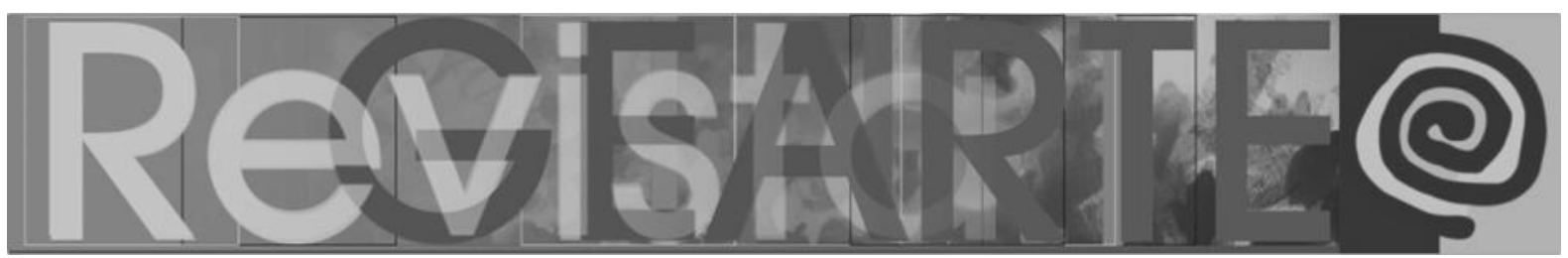

Sérgio é graduado em Pedagogia e sua preocupação em envolver as crianças da comunidade para "mostrar a cultura de Sibaúma" é recorrente, muitas delas participam ativamente das apresentações de coco de zambê. Uma de suas estratégias para despertar esse interesse, compreende a reprodução miniaturizada dos tambores e berimbaus, ofício igualmente realizado por ele.

Os objetos lúdicos são confeccionados com materiais distintos daqueles empregados para a realização dos instrumentos em tamanho real. Para os tambores, é feita a coleta de bambu nas matas da região. Nesse momento, tanto serve a haste do bambu verde ou seco, porém, após o corte, é necessário deixálo secar por quinze dias, depois disso, é retirada a parte da "capa de dentro" para ampliar a espessura interna e oca. Não há padrões para a realização do corte do bambu para a feitura dos tambores, pois observamos variações de tamanho e espessura. $O$ trabalho seguinte é lixar.

Para o "couro" da miniatura do tambor ou pau furado, são utilizados pedaços de aventais de cozinha industrializados, feitos de napa (espécie de tecido sintético que imita um pouco a textura do couro em sua superfície e que possui a elasticidade de uma malha, adquiridos no comércio popular de Goianinha/RN). Na sequência, pedaços do avental são recortados na forma de círculos e fixados no bambu com pistola de cola quente. Se forem empregadas sobras de couro animal, repete-se o mesmo processo para o seu tratamento, conforme anteriormente descrito na elaboração dos instrumentos maiores. O trabalho é concluído com a pintura "abrindo letras", essa expressão indica a existência de palavras ou frases na superfície pintada, feitas com esmalte sintético em cores diversas, apesar de Sérgio preferir o azul e o branco, trabalho similar ao que é feito nos instrumentos maiores. A pintura pode apresentar a assinatura do artista, datas ou o título dos eventos organizados na comunidade pelo grupo Herdeiros de Zumbi: Noite dos Tambores ou Dia da Consciência Negra. 


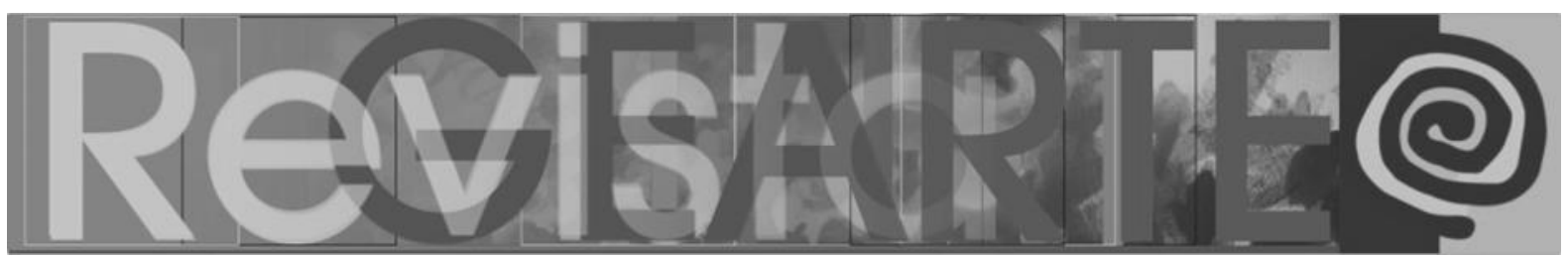

As miniaturas do berimbau são feitas com pedaços de cabaça, varinhas finas de angélica (planta arbustiva e nativa encontrada nas matas no entorno de Sibaúma), barbante de algodão, arame de máquina de lavar roupas ou de ventilador. As hastes de angélica são recolhidas na mata, raspadas e cortadas em pedaços. Depois são envergadas e fixadas com um pedaço do arame. A seguir, é feita uma amarração com cordão de algodão para o acabamento, o processo prossegue quando as hastes já envergadas são coladas num pedaço pequeno e perfurado de cabaça que serve de base. Próximo à base, um outro pedaço desse material é preso com cordão para imitar um caxixi. A pintura com esmalte sintético finaliza o trabalho.

É desejo de Laelson e Silvinho, que num futuro breve, as crianças da comunidade, participantes dos ensaios e apresentações de zambê, também aprendam a confeccionar seus próprios instrumentos, justificando dessa forma a continuidade dos saberes repassados entre gerações mediante a internalização dos processos de aprendizagem. Para isso, buscam concluir um centro cultural, ambiente comunitário situado no quintal da casa de Laelson, em Sibaúma, onde possam ensaiar sem preocupações, oferecer um ponto de apoio para grupos convidados, expor objetos relativos à memória da capoeira e do coco de zambê em Sibaúma, produzir os instrumentos musicais, suas representações miniaturizadas e recepcionar o público em geral, visitantes, pesquisadores e demais interessados em acessar e partilhar sons e saberes ancestrais.

\section{Referências}

ALVES, Teodora de Araújo. Herdanças de corpos brincantes: corporeidade/africanidade em danças afro-brasileiras. 2003. 179 f. Tese (Doutorado em Educação) - Universidade Federal do Rio Grande do Norte, Natal, 2003. Disponível em: https://docplayer.com.br/46627432-Herdancas-de-corposbrincantes-os-saberes-da-corporeidade-africanidade-em-dancas-afro-brasileiras.html. Acesso em: 6 jul. 2019.

BRITO, Alexandre Marcos de. Beabá da capoeira: iniciação ao jogo. Natal: Lucgraf, 2008.

CAVIGNAC, Julie Antoinete; LINS, Cyro Holando de Almeida; MAUX, Augusto. De 'herdeiros' a 'quilombolas': identidades em conflito (Sibaúma - RN). In: ENCONTRO ANUAL DA ANPOCS, 30., 2006, Caxambu. Anais [...]. Caxambu: Anpocs, 2006. Disponível em: https://repositorio.ufrn.br/jspui/handle/123456789/19008. Acesso em: 10 abr. 2020. 


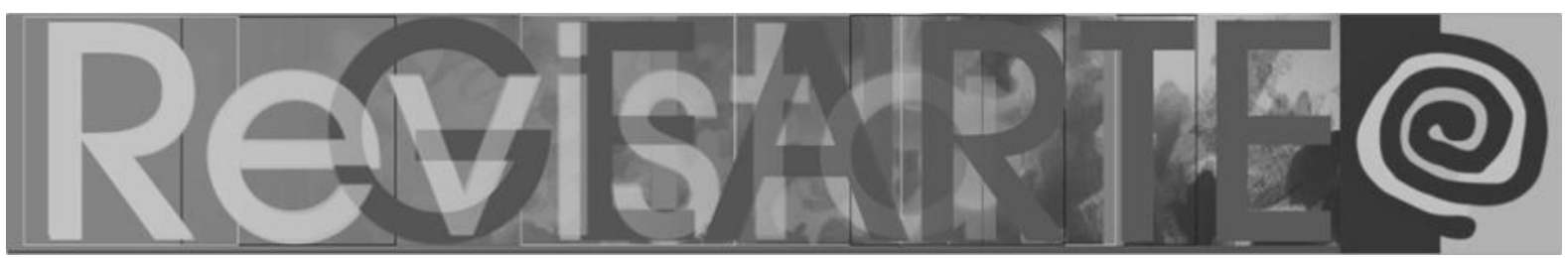

LIMA, Ricardo Gomes. Objetos: percursos e escritas culturais. São José dos Campos: Centro de Estudos da Cultura Popular: Fundação Cultural Cassiano Ricardo, 2010.

LINS, Cyro Holando de Almeida. O zambê é nossa cultura: o coco de zambê e a emergência étnica em Sibaúma, Tibau do Sul-RN. 2009. 107 f. Dissertação (Mestrado em Antropologia Social) Universidade Federal do Rio Grande do Norte, Natal, 2009. Disponível em: https://repositorio.ufrn.br/jspui/handle/123456789/12260. Acesso em: 8 jun. 2019.

LODY, Raul. Coco, comida, cultura e patrimônio. São Paulo: Editora Senac, 2011.

LORENZI, Harri. Árvores brasileiras: manual de identificação e cultivo de plantas arbóreas nativas do Brasil. Nova Odessa: Plantarum, 1998. v. 2.

\section{Nilton Xavier Bezerra}

Nilton Xavier Bezerra é professor de Arte - Artes Visuais - do Instituto Federal do Rio Grande do Norte, Canguaretama, doutorando em Educação Profissional pelo PPGEP/IFRN, Mestre e Especialista em Antropologia Social pelo Programa de Pós-Graduação em Artes Visuais, da Universidade Federal do Rio Grande do Norte. Pesquisa na área de artes visuais, cultura material e cultura popular.

ORCID: https://orcid.org/0000-0002-9821-268X

E-mail: nilton.xavier@ifrn.edu.br

Currículo: http://lattes.cnpq.br/3609163207351583

Recebido em 30 de julho de 2020 Aceito em 18 de setembro de 2020 